\title{
MAKNA, KEDUDUKAN, DAN IMPLIKASI HUKUM HALUAN NEGARA DALAM SISTEM KETATANEGARAAN INDONESIA
}

\author{
I Wayan Sudirta \\ Fakultas Hukum, Universitas Kristen Indonesia \\ Jalan Diponegoro 82-86, Salemba, Jakarta Pusat, 13510 \\ Email :wayansudirtakarangasem@gmail.com
}

\begin{abstract}
Abstrak
Penelitian ini bertujuan untuk menelaah hakikat Haluan Negara dalam sistem ketatanegaraan Indonesia dengan pendekatan filsafat kenegaraan Pancasila. Untuk melihat ketersesuian Haluan Negara dengan sistem ketatanegaraan Indonesia perlu didudukkan kembali hakikat Haluan Negara dengan menggali maksud (original intent) Haluan Negara dari para pendiri bangsa. Melalui pendekatan filsafat kenegaraan Pancasila dan meode penelitian normatif dapat diketahui pertama, bahwa terdapat tiga konsensus dasar yang disepakati oleh para pendiri bangsa sebagai upaya untuk mewujudkan tujuan negara, yang ketiganya menunjukkan hubungan integral yang saling berkait kelindan sebagai triangle of basic state consensus, yaitu Pancasila sebagai dasar falsafah negara (philosofische grondslag), UUD 1945 sebagai hukum dasar negara, dan Haluan Negara sebagai pedoman kebijakan dasar negara. Kedua, Haluan Negara tidak bertentangan dengan sistem presidensil dengan cara menempatkannya dalam konstitusi. Bentuk hukum Haluan Negara melalui Ketetapan MPR yang berkedudukan di bawah Konstitusi membuat perencanaan pembangunan nasional tidak menjadi domain presiden saja tetapi hasil kesepakatan bersama seluruh rakyat dan mengikat seluruh penyelenggara negara.
\end{abstract}

Kata kunci: Haluan Negara, Filsafat Kenegaraan, Kebijakan Dasar Negara.

\begin{abstract}
This research aims to examine the essence of the Directive Principle of State Policy in the Indonesian constitutional system with the Pancasila state philosophy approach. Therefore, to see the compatibility of the Directive Principle of State Policy with the Indonesian constitutional system needs to reclaim the essence of the Directive Principle of State Policy by exploring the original intent of term from the founding fathers the nation. Through the Pancasila state philosophy approach and normative research methods, it can be seen first, that there are three basic consensus agreed upon by the founding fathers the nation as an effort to realize the goals of the state, all of which show an integral relationship which is interrelated as a triangle of basic state consensus, namely Pancasila as the basic philosophy of the state (philosofische grondslag), the 1945 Constitution as the basic law of the state, and the Directive
\end{abstract}


Principle of State Policy as a guide for basic state policies. Second, the Directive Principle of State Policy does not conflict with the presidential system by placing it in the constitution. The legal form of State Direction through the MPR Decree which is domiciled under the Constitution makes national development planning not only the domain of the president but the result of a joint agreement of all the people and binding on all state administrators.

Keywords: The Directive Principle of State Policy, State Philosophy, The Basic State Policies.

\section{A. PENDAHULUAN}

Permasalahan ketatanegaraan yang mengemuka akhir-akhir ini adalah tentang Haluan Negara. Istilah haluan negara sendiri dipergunakan dalam UUD 1945 sebelum amandemen. Ketentuan Pasal 3 UUD 1945 sebelum amandemen menyebut "MPR menetapkan UUD dan garis-garis besar daripada haluan negara" dan Penjelasannya menyatakan: “...DPR senantiasa dapat mengawasi tindakan-tindakan Presiden dan jika Dewan menganggap bahwa Presiden sungguh melanggar haluan negara yang telah ditetapkan oleh undang-undang dasar atau Majelis Permusyawaratan Rakyat...”. Dalam konstruksi diatas, haluan negara mempunyai makna sebagai pedoman bagi penyelenggaraan negara. Berdasarkan pengalaman UUD 1945 Sebelum amandemen, Jimly Asshidiqie berpendapat bahwa haluan negara mencakup pengertian: ${ }^{1}$

a. Haluan negara yang tercantum dalam UUD 1945;

b. Haluan negara yang tertuang dalam ketetapan-ketetapan MPR/S;

c. Haluan negara dalam pengertian program kerja yang tertuang dalam Ketetapan MPR tentang GBHN; dan

d. Haluan negara yang tertuang dalam UU APBN.

Dalam konteks Indonesia, Haluan Negara dibutuhkan oleh bangsa Indonesia sebagai bangsa yang sedang membangun (developing country) untuk memperkuat arah

\footnotetext{
${ }^{1}$ Jimly Assihidiqie, Konstitusi Ekonomi, Jakarta: Kompas Media Nusantara, 2010, Hlm. 18.
} 
dan kepastian pembangunan dalam mewujudkan tujuan negara. Tujuan negara Indonesia sendiri telah ditetapkan dengan jelas dalam Pembukaan UUD 1945, yaitu: "melindungi segenap bangsa Indonesia dan seluruh tumpah darah Indonesia dan untuk memajukan kesejahteraan umum, mencerdaskan kehidupan bangsa, dan ikut melaksanakan ketertiban dunia yang berdasarkan kemerdekaan, perdamaian abadi dan keadilan sosial."

Tujuan negara yang termaktub dalam konstitusi tersebut menjadi landasan filosofis dalam pembangunan negara di segala bidang. Dalam kaitan ini, Haluan Negara menjadi wadah penjabaran tujuan negara yang berfungsi sebagai pedoman dan arah pembangunan negara.

Sejarah menunjukkan bahwa keberadaan Haluan Negara dalam sistem ketatanegaraan Indonesia mengalami perubahan. Di era Orde Lama dan Orde Baru, Haluan Negara perannya menjadi sangat vital sebagai pedoman pembangunan negara, yang kala itu wujud formalnya disebut sebagai Garis-Garis Besar Haluan Negara $(\mathrm{GBHN}) .^{2}$ Namun, setelah reformasi eksistensi Haluan Negara menjadi hilang seiring diamandemen UUD 1945 yang menghilangkan eksistensi Haluan Negara dalam konstitusi. $^{3}$

Setelah era reformasi, peran GBHN sebagai haluan negara yang berfungsi sebagai pedoman dan arah pembangunan negara digantikan oleh Sistem Perencanaan

\footnotetext{
${ }^{2}$ Istilah GBHN ini muncul dari penafsiran Pasal 3 UUD 1945 (sebelum amandemen) yang menyatakan, "Majelis Permusyawaratan Rakyat menetapkan Undang-Undang Dasar dan garis-garis besar daripada haluan negara". Kemudian dalam perjalanannya dituangkan dalam bentuk hukum Ketetapan MPR.

${ }^{3}$ Pasal 3 UUD 1945 sebelum amandemen yang berbunyi, "Majelis Permusyawaratan Rakyat menetapkan Undang-Undang Dasar dan Garis-Garis Besar dari pada Haluan Negara", dirubah rumusannya menjadi "Majelis Permusyawaratan Rakyat berwenang mengubah dan menetapkan Undang-Undang Dasar". Lihat Pasal 3 ayat (1) UUD Tahun 1945.
} 
Pembangunan Nasional (SPPN), ${ }^{4}$ dengan berbagai instrumen turunannya seperti Rencana Pembangunan Jangka Panjang Nasional (RPJPN) ${ }^{5}$ serta Rencana Pembangunan Jangka Menengah Nasional (RPJMN). Namun seiring berjalannya waktu, SPPN dirasa belum mampu berperan sebagai haluan negara dan belum dapat disebut sebagai Haluan Negara. Oleh karena itu belakangan ini muncul upaya untuk menata kembali sistem perencanaan pembangunan nasional agar dapat menjamin arah dan kepastian pembangunan dalam system ketatanegaraan Indonesia melalui rekonstruksi Haluan Negara. Namun tidak dapat dipungkiri, upaya merekonstruksi Haluan Negara menghadirkan perdebatan dan perbedaan pendapat di kalangan ahli hukum tata negara. Perdebatan itu menunjukkan adanya kekaburan pandangan dalam memahami hakikat Haluan Negara. Bahkan ada kecenderungan tiap orang menafsirkan Haluan Negara itu menurut kehendaknya sendiri, tanpa usaha untuk menggali dan memahami maksud (original intent) istilah Haluan Negara itu dalam pemahaman para pendiri bangsa.

Oleh karena itu, langkah yang paling bijak menurut penulis adalah mengembalikan pengertian Haluan Negara kepada hakikatnya. Untuk melihat hakikat Haluan Negara lebih dalam, maka dapat dilakukan dengan pendekatan filsafat kenegaraan yang dianut oleh bangsa Indonesia. Melalui pendekatan filsafat kenegaraan akan diketahui hubungan Haluan Negara dengan UUD 1945 sebagai norma/hukum dasar dan Pancasila sebagai philosofische grondslag. Bertolak dari pemikiran di atas, penelitian ini akan mengkonstruksikan lebih lanjut 2 (dua) permasalahan, yaitu Pertama,

\footnotetext{
${ }^{4}$ Republik Indonesia, Undang-Undang Nomor 25 Tahun 2004 tentang Sistem Perencanaan Pembangunan Nasional.

${ }^{5}$ Republik Indonesia, Undang-Undang Nomor 17 Tahun 2007 tentang Rencana Pembangunan Jangka Panjang Nasional Tahun 2005 - 2025.
} 
bagaimanakah makna dan kedudukan hukum haluan negara sehingga dapat dikualifikasikan sebagai dasar pembentukan hukum di indonesia? dan Kedua, bagaimana implikasi hukum makna dan kedudukan haluan negara dalam sistem ketatanegaraan indonesia?

\section{B. METODE PENELITIAN}

Penelitian ini merupakan penelitian hukum (legal research) yang menggunakan beberapa pendekatan untuk menjawab permasalahan yan diteliti, yaitu: 1) pendekataan undang-undang (statute approach), 2) pendekatan konseptual (concentual approach), 3) pendekatan perbandingan (comparation approach), dan 4) pendekatan historis dan filosofis (historical approach) dan (philosophy approach).

Data yang diperlukan dalam penelitian ini yang utama adalah data sekunder. Data sekunder diperoleh dengan melakukan studi terhadap dokumen:

a. Bahan hukum primer, yaitu baham-bahan hukum yang mengikat berupa UUD hingga peraturan perundang-undangan di bawahnya dan dokumen hukum lainnya;

b. Bahan hukum sekunder yang memberikan penjelasan mengenai bahan hukum primer, yaitu risalah sidang mulai dari risalah sidang BPUPKI, PPKI, amandemen UUD 1945 dan bahan-bahan hasil penelitian yang terkait dengan tema utama penelitian ini dan hasil-hasil pembahasan di berbagai forum ilmiah lainnya;

c. Bahan hukum tertier atau bahanbahan hukum penunjang seperti kamus, ensiklopedia, dan bahan lainnya yang melengkapi data penelitian. 
Pengolahan data dilakukan secara kualitatif. Bahan-bahan hukum tertulis yang telah dikumpulkan kemudian dilakukan sistematisasi sesuai dengan permasalahan yang diteliti. Selanjutnya bahan hukum tersebut dikaji dan diuraikan sesuai dengan permsalahannya dengan menggunakan landasan teori yang relevan. Untuk menjawab permasalahan, terhadap bahan hukum yang telah disistematisasi kemudian dilakukan penilaian sehingga dapat menjawab dengan tepat makna dan kedudukan serta implikasi hukum Haluan Negara dalam sistem ketatanegaraan Indonesia.

\section{PEMBAHASAN}

\section{Makna dan Kedudukan Haluan Negara}

Istilah Haluan Negara muncul dari penafsiran Pasal 3 UUD 1945 (sebelum amandemen). ${ }^{6}$ Menurut Yudi Latif, Haluan Negara dapat dibagi menjadi 2 (dua) substansi yaitu, pertama, Haluan Negara yang bersifat ideologis berisi prinsip-prinsip fundamental sebagai kaidah penuntun dalam menjabarkan falsafah negara dan pasalpasal konstitusi ke dalam peraturan perundang-undangan dan kebijakan pembangunan di segala bidang dan lapisan. Sedangkan substansi yang kedua, adalah Haluan Negara yang bersifat strategis berisi pola perencanaan pembangunan yang menyeluruh, terpadu, dan terpimpin dalam jangka panjang secara bertahap dan berkesinambungan, dengan memperhatikan prioritas bidang dan ruang. ${ }^{7}$

\footnotetext{
${ }^{6}$ Pasal 3 UUD 1945 sebelum amandemen menyatakan, "Majelis Permusyawaratan Rakyat menetapkan Undang-Undang Dasar dan Garis-Garis besar daripada haluan negara".

${ }^{7}$ Yudi Latif, Rancang Bangun GBHN, Kompas, Edisi 30 Agustus 2016.
} 
Haluan Negara jika dihubungkan dengan filsafat kenegaraan secara prinsipil mengandung dua tuntunan, yakni haluan yang bersifat ideologis dan haluan yang bersifat strategis-teknokratis. Menurut Yudi Latif Haluan yang bersifat ideologis berisi prinsip-prinsip fundamental sebagai kaidah penuntun dalam menjabarkan falsafah negara dan pasal-pasal konstitusi ke dalam peraturan perundang-undangan dan kebijakan pemerintahan. Sedangkan haluan yang bersifat strategis berisi pola perencanaan pembangunan yang menyeluruh, terpadu, dan terpimpin dalam jangka panjang secara bertahap dan berkesinambungan, dengan memperhatikan prioritas bidang dan ruang. ${ }^{8}$

Para pendiri bangsa sepakat bahwa Haluan Negara diciptakan sebagai perangkat guna menuntun penyelenggara pemerintahan negara dalam upaya mewujudkan tujuan bernegara. Soepomo dalam pidato laporan Panitia Kecil (Panitia Sembilan) Panitia Persiapan Kemerdekaan Indonesia (PPKI) tanggal 15 Juli 1945 menegaskan hal tersebut sebagai berikut: ${ }^{9}$

“Oleh karena madjelis permusjawaratan itulah jang memegang haluan rakyat, jang memang mempunyai kekuasaan tertinggi jang tak terbatas, maka sudah selajaknya Madjelis Permusyawaratan Rakjat jang pada haluan kita mengingat dinamik, kehidupan, tumbuhnya masyarakat. Djadi itu adalah sekali dalam 5 tahun; sesudah 5 tahun sudah tentu rakjat atau badan permusjawaratannja ingat, apa yang terdjadi dan aliran apa jang ada diwaktu itu, dan pula haluan manakah jang baik untuk kemudian hari; dan djika

\footnotetext{
${ }^{8}$ Ibid.

${ }^{9}$ Sekretariat Negara, Himpunan Risalah Sidang-Sidang Badan Penyelidik Usaha Kemerdekaan Indonesia (BPUPKI) tanggal 29 Mei - 16 Juli 1945 dan Panitia Persiapan Kemerdekaan Indonesia (PPKI), tanggal 18-19 Agustus 1945 Yang Berhubungan Dengan Penyusunan Undang-Undang Dasar 1945, Hlm. 541-543.
} 
perlu sudah tentu akan merobah Undang-undang Dasar. Maka dengan itu panitia jakin, bahwa Undang-undang akan senantiasa menurut haluan jang hendak dikerdjakan oleh Pemerintah.”

Penegasan Soepomo sebagaimana disampaikan diatas, sebenarnya merupakan wujud dari manifestasi yang dikembangkan oleh para pendiri bangsa pada waktu pembahasan UUD 1945. Pertama, menyangkut dasar negara; Kedua, berkaitan erat dengan hubungan rakyat dan pemerintah; dan Ketiga menyangkut tujuan negara.

Penjelasan diatas menunjukkan bahwa secara ontologis terdapat 2 (dua) aspek penting sebagai unsur utama dalam Haluan Negara, yaitu: pertama, prinsip-prinsip direktif; dan kedua, kebijakan dasar negara. Atas dasar tersebut, sebenarnya Haluan Negara dibangun sebagai bentuk konsepsi dari 3 (tiga) konsensus dasar yang disepakati oleh para pendiri bangsa Indonesia sebagai upaya untuk mewujudkan tujuan negara, yaitu Pancasila, UUD 1945, dan Haluan Negara. Ketiganya saling berkait kelindan dan saling menopang antar satu dengan yang lainnya yang disebut sebagai triangle of basic state consensus, ${ }^{10}$ sebagaimana yang dapat disajikan dalam gambar di bawah ini.

Gambar 1. Triangle of Basic State Consensus: Pancasila, UUD 1945, dan Haluan Negara

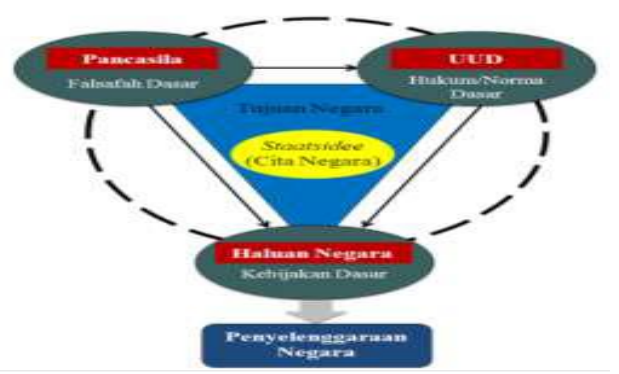

10 Lutfil Ansori, Haluan Negara Sebagai Pedoman Kebijakan Dasar Negara Dalam Sistem Ketatanegaraa Indonesia: Sebuah Tinjauan Filsafat Kenegaraan, Justicia Islamica: Jurnal Kajian Hukum dan Sosial, Vol. 16, No.1, Juni 2019, Hlm. 94. 
Uraian diatas merupakan gambaran utuh bagaimana konstruksi bernegara disusun oleh para pendiri bangsa pada waktu itu. Nilai-nilai filosofis Pancasila yang bersifat abstrak dan pasal-pasal Konstitusi berisi norma-norma besar yang tidak memberikan arahan bagaimana cara melembagakannya dipertegas kembali melalui Haluan Negara. Dengan demikian Haluan Negara mempunyai makna dan kedudukan sebagai kaidah penuntun (guiding principles) yang berisi arahan dasar (directive principles) tentang bagaimana cara melembagakan nilai-nilai Pancasila dan Konstitusi itu ke dalam kebijakan publik.

Haluan Negara dalam hal ini memandu para penyelenggara negara dalam merumuskan dan menjalankan kebijakan sehingga sesuai dengan tujuan bernegara yang termaktub dalam Pembukaan UUD 1945. Itu sebabnya Haluan Negara yang menjadi satu kesatuan yang melengkapi keberadaan Pancasila dan UUD 1945. Tujuan negara menjadi inti yang hendak dicapai oleh negara yang sekaligus memandu arah penyelenggaraan negara, yang di dalamnya terkandung cita negara (staatsidee). Staatsidee merupakan hakikat dari negara, dimana staatsidee ini menjadi cikal bakal bagi terbentuknya negara.

Pancasila sebagai konsensus pertama adalah dasar falsafah negara (philosofische grondslag), yang di dalamnya mengandung prinsip-prinsip filosofis. Pancasila adalah dasar statis yang mempersatukan sekaligus bintang penuntun (Leitstar) yang dinamis, yang mengarahkan bangsa dalam mencapai tujuannya; UUD 1945 sebagai consensus kedua adalah hukum/norma dasar, yang berisi prinsip-prinsip normatif yang mengatur keseluruhan sistem ketatanegaraan; dan Haluan Negara sebagai konsensus ketiga 
berkedudukan sebagai kebijakan dasar, yang mengandung prinsip-prinsip direktif. Prinsip direktif itu merupakan panduan yang mengarahkan haluan kebijakan negara bagi seluruh Lembaga negara, pemerintah pusat dan daerah yang harus dijadikan pegangan sebagai kerangka kerja dalam merumuskan materi perundang-undangan dan programprogram pemerintahan.

Dalam kedudukan yang demikian, Haluan Negara berfungsi sebagai pedoman kebijakan dasar dari negara. Bila mencermati Haluan Negara sejak awal dalam bentuk Pembangunan Nasional Semesta Berencana (PNSB) pada era Orde Lama yang difungsikan sebagai pedoman kebijakan politik, Garis-Garis Besar Haluan Negara (GBHN) pada era Orde Baru yang lebih difungsikan sebagai pedoman kebijakan pembangunan nasional, dan GBHN pada era Reformasi yang dimaksudkan sebagai pedoman kebijakan penyelenggaraan negara. Haluan Negara pada kenyataannya disetiap masa pemerintahan diberi aksentuasi yang berbeda, namun fungsinya tetap sama yakni sebagai pedoman kebijakan dasar dari negara.

Pemahaman di atas mengindikasikan bahwa mekanisme politik dan demokrasi sangat mempengaruhi penyusunan Haluan Negara pada waktu ke waktu. Oleh karena itu Haluan Negara ke depan sebagai dokumen hukum yang bersifat teknis operasinal dalam mewujudkan arah dan tujuan bernegara sebagaimana diamanatkan oleh alenia keempat Pembukaan UUD 1945, materi muatannya tidak boleh menyimpang dari Pancasila sebagai sumber dari segala sumber hukum dan UUD 1945. Penyusunannya oleh MPR harus benar-benar memperhatikan pendapat rakyat. Hakikatnya inilah yang menjadi ciri utama Indonesia sebagai negara hukum Pancasila. 


\section{Implikasi Hukum Makna dan Kedudukan Haluan Negara}

Haluan Negara yang pernah ada di Indonesia mulai dari Ketetapan MPRS Nomor I/MPRS/1960 tentang Manifesto Politik Republik Indonesia sebagai Garis-Garis Besar dari pada Haluan Negara, ${ }^{11}$ Haluan Negara pada masa Orde Baru, ${ }^{12}$ sejak tahun 1969 hingga 1998, tercatat ada 6 (enam) Ketetapan MPR (Tap MPR) tentang GBHN, yaitu: 1) Ketetapan MPR Nomor IV/MPR/1973; ${ }^{13}$ 2) Ketetapan MPR Nomor IV/MPR/ 1978; 3) Ketetapan MPR Nomor II/MPR/1983; 4) Ketetapan MPR Nomor II/MPR/1988; 5) Ketetapan MPR Nomor II/MPR/1993; dan 6) Tap MPR Nomor II/MPR/1998. ${ }^{14}$ Pada masa reformasi lahir GBHN terakhir melalui Ketetapan MPR Nomor IV/MPR/1999 tentang Garis-Garis Besar Haluan Negara Tahun 1999-2004. GBHN 1999-2004 mempunyai materi muatan yang berbeda dengan GBHN zaman Orde Baru, dengan perubahan yang cukup fundamental. Pada zaman Order Baru, GBHN

\footnotetext{
${ }^{11}$ Merupakan penetapan MPR atas Penetapan Presiden Nomor 1 Tahun 1960 tentang Garis-garis Besar daripada Haluan Negara. Dalam Pasal 1 Penpres tersebut dinyatakan bahwa sebelum Majelis Permusyawaratan Rakyat terbentuk maka Manifesto Politik Republik Indonesia yang diucapkan pada tanggal 17 Agustus 1959 oleh Presiden/Panglima Tertinggi Angkatan Perang adalah garis-garis besar dari pada haluan negara.

${ }_{12}$ Titik tekan Haluan Negara ada pada pembangunan nasional, yang ketika itu juga diwadahi dalam bentuk GBHN. Pelaksanaan GBHN kemudian dijabarkan dalam Rencana Pembangunan Lima Tahun (Repelita) yang telah berjalan dari kurun waktu tahun 1969 (Repelita I) sampai dengan tahun 1998 (Repelita VI).

${ }^{13}$ Dalam Tap MPR No. IV/MPR/1973 dirumuskan pengertian GBHN sebagai "Haluan Negara dalam garis-garis besar yang pada hakikatnya adalah suatu pola Umum Pembangunan Nasional yang ditetapkan oleh MPR". Dalam Tap MPR No. II/MPR/ 1978, Tap MPR No. IV/MPR/1983, dan Tap MPR No. II/MPR/1988 pada dasarnya sama dengan GBHN yang tertuang dalam Tap MPR No. IV/MPR/1973. GBHN dalam Tap-Tap tersebut dimaknai sebagai haluan negara dalam garis-garis besar yang pada hakikatnya adalah suatu pola pembangunan nasional yang meliputi Pola Dasar Pembangunan Nasional, Pola Umum Pembangunan Jangka Panjang, serta Pola Umum Pembangunan Lima Tahun.

${ }^{14}$ Pengertian GBHN menurut Tap MPR No. II/MPR/1993 dan Tap MPR No.II/MPR/1998 adalah Haluan Negara tentang pembangunan nasional dalam garis garis besar sebagai pernyataan kehendak rakyat yang ditetapkan oleh MPR setiap lima tahun.
} 
merupakan Haluan negara tentang pembangunan nasional, sementara GBHN era reformasi merupakan haluan penyelenggaraan negara. ${ }^{15}$

Pada sisi kewenangan dalam membentuk GBHN, MPR menjadi Lembaga yang berwenang menetapkan GBHN sebagaimana ketentuan Pasal 3 UUD 1945 sebelum amandemen. Bagir Manan menyatakan bahwa kewenangan penyusunan GBHN kepada MPR sebagaimana UUD 1945 sebelum amandemen, tidak dapat dilepaskan dari soal kedaulatan rakyat. Lebih jauh Bagir Manan menyampaikan "Keinginan para pendiri negara yang terarah dan terbimbing. Sebagai penjelmaan kedaulatan rakyat yang terarah dan terbimbing, diciptakan system garis-garis besar daripada haluan negara bukan sekedar system kerja atas perencanaan (planning system) tetapi sebagai sarana melaksanakan kedaulatan rakyat yang terarah dan terbimbing." 16

Penafsiran yang dilakukan Bagir Manan bukan tanpa alasan apabila dihubungkan dengan konteks penyusunan UUD 1945 yang meletakkan kewenangan MPR sebagai perwujudan kedaulatan rakyat sebagaimana Pasal 1 ayat (2) UUD 1945 sebelum amandemen. Sekalipun UUD 1945 pasca amandemen mengkonstruksikan kedaulatan rakyat tidak lagi bersifat tunggal menjadi otoritas MPR, namun dengan melekatnya hak-hak konstitusional MPR untuk melakukan perubahan UUD, menegaskan kedudukan MPR dalam sistem ketatanegaraan Indonesia menjadi penting dan strategis.

\footnotetext{
${ }^{15}$ Menurut Tap MPR No. IV/MPR/1999, pengertian Garis-Garis Besar Haluan Negara adalah haluan negara tentang penyelenggaraan negara dalam garis-garis besar sebagai pernyataan kehendak rakyat secara menyeluruh dan terpadu yang ditetapkan oleh Majelis Permusyawaratan Rakyat untuk lima tahun guna mewujudkan kesejahteraan rakyat yang berkeadilan.

${ }^{16}$ Susi Dwi Harijanti, Merumuskan Ulang Garis-Garis Besar Haluan Negara, Jurnal Majelis MPR RI, 2016, edisi 4, Hlm. 18-19.
} 
Sesuai dengan semangat pembentukan MPR, MPR dikonstruksikan sebagai lembaga yang mewakili berbagi unsur kekuatan kebangsaan. Hal ini senafas dengan semangat kekeluargaan dalam alam demokrasi permusyawaratan. Oleh karena itu, seluruh rakyat, seluruh golongan, dan seluruh daerah akan memiliki wakil dalam MPR. ${ }^{17}$ Dengan kedudukan yang demikian, sekalipun amandemen UUD 1945 telah menghilangkan salah satu kewenangan MPR dalam menyusun GBHN dan didistribusikannya kedaulatan rakyat dalasecara fungsional kepada Lembaga-lembaga negara lainnya sesuai dengan UUD, belumlah dapat dikategorikan sebagai upaya utnuk menghilangkan konsepsi awal MPR sebagai pengejawantahan kedaulatan rakyat, karena tetap MPR merupakan permusyawaratan tertinggi pada waktu menyusun dan menetapkan UUD.

Demikian pula dalam memaknai GBHN sebagai Haluan Negara dalam sistem ketatanegaraan Indonesia, GBHN merupakan upaya penyusunan gagasan filosofis dan strategis terkait dengan kepentingan untuk mewadai tujuan berbangsa dan bernegara sebagaimana Pembukaan UUD 1945. GBHN adalah garis lurus untuk mengkonkretkan Pancasila dan UUD 1945 dalam sebuah dokumen pedoman bagi penyelenggaraan negara. Sebagaimana disampaikan di atas, bahwa GBHN atau Haluan Negara merupakan pilar dari triangle state concensus yang merupakan kelindan antara Pancasila, UUD 1945, dan Haluan Negara sebagai pokok pedoman berbangsa dan bernegara. Dengan kedudukan ini, Haluan Negara berfungsi sebagai tafsir resmi negara terhadap Pancasila dan UUD 1945.

\footnotetext{
${ }^{17}$ Yudi Latief, Negara Paripurna: Historisitas, Rasionalitas, dan Aktulitas Pancasila, Jakarta: Kompas Gramedia, 2001, Hlm. 437.
} 
Dengan makna dan kedudukan Haluan Negara yang demikian, maka adanya Haluan Negara dalam sistem ketatanegaraan Indonesia tidak akan mempengaruhi sistem presidensil yang telah ditetapkan amandemen UUD 1945. Jimly Asshidiqie menyampaikan bahwa Haluan Negara sudah jamak diberlakukan di banyak negara, dengan meletakkan substansi haluan negara ini dalam konstitusinya terkait dengan masalah-masalah yang dianggap penting. Konstitusi Irlandia sebagai contohnya mengatur Directive Principles of State Policy (DPSP) yang mengatur mengenai ekonomi, pasar bebas, dan masalah intervensi negara. Beberapa contoh negara yang meletakkan Haluan Negara atau DPSP dalam Konstitusinya dapat disimak dalam tabel berikut: ${ }^{18}$

Tabel 2. Perbandingan Negara Yang Menerapkan Haluan Negara

\begin{tabular}{|l|l|l|}
\hline Negara & \multicolumn{1}{|c|}{$\begin{array}{c}\text { Sistem } \\
\text { Pemerintahan }\end{array}$} & \multicolumn{1}{c|}{$\begin{array}{c}\text { Haluan } \\
\text { Negara }\end{array}$} \\
\hline Irlandia $^{19}$ & Sistem Parlementer & $\begin{array}{l}\text { Disebutkan secara tegas dalam Pasal 45 Konstitusi } \\
\text { Irlandia 2015 yang berjudul Directive Principles of } \\
\text { Social Policy. }\end{array}$ \\
\hline India $^{20}$ & Sistem Parlementer & $\begin{array}{l}\text { Disebutkkan secara tegas dalam Bab IV Konstitusi } \\
\text { India dengan judul Directive Principles of State } \\
\text { Policy. }\end{array}$ \\
\hline Filipina $^{21}$ & Sistem Presidensil & $\begin{array}{l}\text { Disebutkan secara tegas dalam Pasal II Konstitusi } \\
\text { Filipina 1987 dengan Declaration of Principles and } \\
\text { State Policies Principles. }\end{array}$ \\
\hline
\end{tabular}

\footnotetext{
${ }^{18}$ Mei Susanto, Wacana Menghidupkan Kembali GBHN Dalam Sistem Presidensil Indonesia, Jurnal Penelitian Hukum DE JURE, Volume 17, Nomor 3, September 2017, Hlm. 436.

19 https://www.gov.ie/en/publication/d5bd8c-constitution-of-ireland/, diunduh tanggal 22 November 2020, Pukul 15.15 WIB.

${ }^{20} \mathrm{http} / / /$ legislative.gov.in/constitution-of-india, diunduh tanggal 22 November 2020, Pukul 5.34 WIB.

${ }^{21}$ https://www.constituteproject.org/constitution/Philippines 1987.pdf?lang=en, diunduh pada tanggal 22 November 2020, Pukul 12.51 WIB.
} 


\begin{tabular}{|l|l|l|}
\hline Negara & \multicolumn{1}{|c|}{$\begin{array}{c}\text { Sistem } \\
\text { Pemerintahan }\end{array}$} & \multicolumn{1}{c|}{$\begin{array}{c}\text { Haluan } \\
\text { Negara }\end{array}$} \\
\hline Brazil $^{22}$ & Sistem Presidensil & $\begin{array}{l}\text { Tidak disebutkan secara tegas dalam Konstitusi } \\
\text { Brazil, namun beberapa pengaturan memperlihatkan } \\
\text { prinsip- prinsip haluan negara. }\end{array}$ \\
\hline $\begin{array}{l}\text { Korea } \\
\text { Selatan }\end{array}$ & Sistem Presidensil & $\begin{array}{l}\text { Tidak disebutkan secara tegas dalam Konstitusi } \\
\text { Korea Selatan, namun beberapa pengaturan } \\
\text { memperlihatkan prinsip-prinsip haluan negara. }\end{array}$ \\
\hline
\end{tabular}

Perbandingan beberapa negara tersebut menunjukkan telah terjadi tren perumusan haluan negara atau DPSP dalam konstitusi, baik secara langsung maupun tidak langsung, yang tidak menggantungkan pada sistem pemerintahan yang dianut. Dengan demikian, terjadi konvergensi yang menunjukkan perlunya haluan negara dalam pembangunan negara tersebut. Apabila dilihat hal tersebut tidak lain karena keterbutuhan negara-negara yang bersangkutan khususnya bagi negara berkembang.

Dengan melihat tren tersebut, maka menempatkan DPSP atau GBHN dalam konstitusi adalah suatu hal yang wajar. Karenanya, materi muatan konstitusi sebagaimana pendapat J.G. Steenbeek yang dikutip Sri Soemantri ${ }^{24}$ yakni 1) Jaminan hak-hak asasi manusia dan warga Negara; 2) Susunan ketatanegaraan yang bersifat fundamental; dan 3) Pembagian dan pembatasan tugas ketatanegaraan yang juga bersifat fundamental, sudah tidak cukup lagi. Selain 3 materi muatan yang prinsip tadi, maka

\footnotetext{
${ }^{22}$ https://www.globalhealthrights.org/wp-content/uploads/2013/09/Brazil-constitution-English.pdf, diunduh pada tanggal 22 November 2020, Pukul 15.19 WIB.

${ }^{23}$ https://www.constituteproject.org/constitution/Republic of Korea_1987.pdf?lang=en, diunduh pada tanggal 22 November 2020, Pukul 13.58 WIB.

${ }^{24}$ Sri Soemantri, Prosedur dan Sistem Perubahan Konstitusi, (Bandung: Alumni, 1987), Hlm. 51.
} 
materi muatan yang berisikan haluan pembangunan negara juga menjadi kebutuhan yang layak dimasukkan. ${ }^{25}$

Dalam alam demokrasi Indonesia, di mana checks and balances serta kedudukan Ketetapan MPR berada di bawah UUD 1945, sejatinya keberadaan Haluan Negara tidak akan menganggu keberlangsungan sistem presidensil, sebab kehadiran Haluan Negara semata-mata untuk mewadahi konsep-konsep bernegara yang demokratis. Keberadaan Haluan Negara nantinya juga akan menjawab permasalahan pengaturan Sistem Perencanaan Pembangunan Nasional (SPPN) yang sifatnya development oriented tanpa melihat keterkaitan sejarah dan kearifan politik yang terbangun pada saat perumusan Pancasila dan UUD 1945.

Sebagai implikasi dengan adanya Haluan Negara ini, dapat disampaikan pemikiran bahwa sebenarnya UUD 1945 setelah amandemen, sebenarnya telah memuat beberapa ketentuan yang berkaitan dengan prinsip penyelenggaraan negara untuk mengurusi pendidikan dan kebudayaan (Bab XIII, Pasal 31 dan 32), serta perekonomian nasional dan kesejahteraan sosial (Bab XIV, Pasal 33 dan 34). Ketentuan tersebut sebenarnya dapat dikatakan sebagai sebuah haluan negara, walaupun tidak diberikan judul "Garis- Garis Besar Haluan Negara". Atas dasar hal tersebut, semestinya ketentuan-ketentuan ini ditegaskan sebagai sebuah haluan negara disertai penyempurnaan-penyempurnaan sehingga dapat dijadikan pedoman pembangunan yang

\footnotetext{
${ }^{25}$ Mei Susanto, Op, cit.,
} 
berkelanjutan serta dapat dilakukan penegakannya. Dari sinilah, cikal bakal Haluan Negara yang termuat dalam Konstitusi Indonesia telah ada. ${ }^{26}$

Selain itu, menempatkan GBHN dalam UUD 1945 dianggap tepat jika dilihat dari basis sosial bangsa Indonesia. Sebagai negara kekeluargaan, maka sudah selayaknya pembangunan nasional tidak dirumuskan sendiri, tetapi harus dirumuskan bersama. Dengan demikian Haluan Negara yang merupakan pedoman pembangunan berkelanjutan merupakan hasil konsensus bersama dari seluruh warga negaranya. Karenanya, selain menempatkan Haluan Negara dalam Bab khusus UUD 1945, patut pula dipikirkan agar MPR dapat kembali menyusun "Ketetapan" mengenai Haluan Negara (GBHN) yang merinci Haluan Negara dalam konsitusi untuk masa 5 (lima) tahun yang digunakan sebagai pedoman lebih lanjut penyelenggara negara. Dengan demikian, pengaturan dimensi-dimensi filosofis dalam Haluan Negara yang ditetapkan dalam Ketetapan MPR itu nantinya akan semakin menguatkan dasar-dasar fundamental dari penyusunan perencanaan pembangunan nasional, penyelenggaraan negara oleh Lembaga negara, pemerintah pusat dan daerah. Hal ini dikarenakan materi muata GBHN akan memuat aspek-aspek filosofis, strategis, dan futuristik sebagai prinsip karena menterjemahkan kehendak Pancasila dan UUD 1945. Sampai disini menjadi jelas, bahwa yang disebut Haluan Negara harus mengandung prinsip-prinsip direktif yang berfungsi sebagai pedoman kebijakan dasar negara atau sebagai kaidah penuntun dalam menjabarkan falsafah negara dan pasal-pasal konstitusi ke dalam kebijakan pembangunan negara.

${ }^{26}$ Ibid. 


\section{PENUTUP}

\section{Kesimpulan}

Dari uraian pembahasan diatas dapat ditarik kesimpulan bahwa makn dan dan kedudukan Haluan Negara dalam sistem ketatanegaraan Indonesia ditinjau dari filsafat kenegaraan Pancasila terlihat bahwa ada tiga konsensus dasar yang disepakati oleh para pendiri bangsa sebagai upaya untuk mewujudkan tujuan negara, yaitu Pancasila, UUD 1945, dan Haluan Negara, yang ketiganya saling berkait kelindan sebagai triangle of basic state consensus. Sehingga keberadaan Haluan Negara menjadi bagian yang tidak terpisahkan dari Pancasila dan UUD 1945.

Sedangkan kaitan Implikasi Hukum Makna dan Kedudukan Haluan Negara Dalam Sistem Ketatanegaraan Indonesia melalui filsafat kenegaraan pula dapat ditunjukkan bahwa Haluan Negara secara ideal seharusnya dirumuskan dalam Konstitusi sebagai Directive Principles of State Policy dan dijabarkan dalam Ketetapan MPR. Oleh karena itu terdapat 2 (dua) elemen penting yang menjadi unsur utama atau objek pokok dalam Haluan Negara, yaitu: pertama, prinsip-prinsip direktif, dan kedua, kebijakan dasar negara. Prinsip-prinsip direktif itu merupakan panduan yang mengarahkan kebijakan negara atau sebagai kaidah penuntun dalam menjabarkan nilainilai Pancasila dan pasal-pasal konstitusi ke dalam kebijakan pembangunan negara.

\section{Saran}

Mengingat begitu pentingnya keberadaan Haluan Negara dalam hubungannya dengan Pancasila dan UUD 1945, maka perlu dilakukan penataan sistem ketatanegaraan Indonesia, dengan menyusun Directive Principles of State Policy dalam UUD, 
penambahan kewenangan MPR untuk menyusun Haluan Negara dan mengeluarkan Ketetapan MPR yang kedudukannya di bawah UUD 1945 hanya khusus untuk menetapkan Haluan Negara.

Materi muatan Haluan Negara nantinya merupakan kehendak dari falsafah Pancasila dan UUD 1945 yang menjadi pedoman bagi Lembaga negara, pemerintah pusat dan daerah.

\section{DAFTAR PUSTAKA}

\section{Peraturan Perundang-Undangan}

Undang-Undang Dasar Negara Republik Indonesia Tahun 1945.

Ketetapan Majelis Permusyawaratan Rakyat Sementara Republik Indonesia Nomor I/MPRS/1960 Tentang Manifesto Politik Republik Indonesia Sebagai GarisGaris Besar Daripada Haluan Negara, kemudian dijabarkan dengan Ketetapan Majelis Permusyawaratan Rakyat Sementara Republik Indonesia Nomor II/MPR/1960 tentang Garis-Garis Besar Pola Pembangunan Nasional Semesta Berencana Tahapan Pertama 1961-1969.

Ketetapan Majelis Permusyawaratan Rakyat Republik Indonesia Nomor IV/MPR/1973 tentang Garis-Garis Besar Haluan Negara.

Ketetapan Majelis Permusyawaratan Rakyat Republik Indonesia Nomor IV/MPR/1978 tentang Garis-Garis Besar Haluan Negara.

Ketetapan Majelis Permusyawaratan Rakyat Republik Indonesia Nomor II/MPR/1983 tentang Garis-Garis Besar Haluan Negara.

Ketetapan Majelis Permusyawaratan Rakyat Republik Indonesia Nomor II/MPR/1988 tentang Garis-Garis Besar Haluan Negara.

Ketetapan Majelis Permusyawaratan Rakyat Republik Indonesia Nomor II/MPR/1993 tentang Garis-Garis Besar Haluan Negara.

Ketetapan Majelis Permusyawaratan Rakyat Republik Indonesia Nomor II/MPR/1998 tentang Garis-Garis Besar Haluan Negara.

Ketetapan Majelis Permusyawaratan Rakyat Republik Indonesia Nomor XVI/MPR/1998 Tentang Politik Ekonomi Dalam Rangka Demokrasi Ekonomi.

Ketetapan Majelis Permusyawaratan Rakyat Republik Indonesia Nomor IV/MPR/1999 tentang Garis-Garis Besar Haluan Negara Tahun 1999-2004. 
Ketetapan Majelis Permusyawaratan Rakyat Republik Indonesia Nomor III/MPR/2000 Tentang Sumber dan Tata Urutan Peraturan Perundang-Undangan.

Ketetapan Majelis Permusyawaratan Rakyat Republik Indonesia Nomor I/MPR/2003 Tentang Peninjauan Terhadap Materi dan Status Hukum Ketetapan Majelis Permusyawaratan Rakyat Sementara dan Ketetapan Majelis Permusywaratan Rakyat Republik Indonesia Republik Indonesia Tahun 1960 Sampai dengan Tahun 2002.

Undang-Undang Nomor 10 Tahun 2004 tentang Pembentukan Peraturan PerundangUndangan. (Lembaran Negara Republik Indonesia Tahun 2004 Nomor 53, Tambahan Lembaran Negara Republik Indonesia Nomor 4389).

Undang-Undang Nomor 25 Tahun 2004 Tentang Sistem Perencanaan Pembangunan Nasional (Lembaran Negara Republik Indonesia Tahun 2004 Nomor 104, Tambahan Lembaran Negara Republik Indonesia Nomor 4421).

\section{Buku, Jurnal Ilmiah dan Koran:}

Arief Sidharta, Bernard, Ilmu Hukum Indonesia: Upaya Pengembangan Ilmu Hukum sebagai landasa Pengembangan Ilmu Hukum Nasional, Yogyakarta: Genta Publising, 2013.

Asshidiqie, Jimly, Konstitusi dan Konstitualisme Indonesia, Jakarta: Mahkamah Konstitusi RI dan Pusat Studi Hukum Tata Negara FH-UI, 2004. , Konstitusi Ekonomi, Jakarta: Kompas Media Nusantara, 2010.

Konstitusi Bernegara Praksis Kenegaraan Bermartabat Dan Demokratis, Malang: Setara Press, 2015.

Dicey, AV. Pengantar Studi Hukum Konstitusi (Terjemahan dari Introduction to the Study of the Constitution), Bandung: Nusamedia, 2008.

Dwi Harijanti, Susi, Merumuskan Ulang Garis-Garis Besar Haluan Negara, Jurnal Majelis MPR RI, 2016, edisi 4.

Lutfil Ansori, Haluan Negara Sebagai Pedoman Kebijakan Dasar Negara Dalam Sistem Ketatanegaraa Indonesia: Sebuah Tinjauan Filsafat Kenegaraan, Justicia Islamica: Jurnal Kajian Hukum dan Sosial, Vol. 16, No.1, Juni 2019.

Mei Susanto, Wacana Menghidupkan Kembali GBHN Dalam Sistem Presidensil Indonesia, Jurnal Penelitian Hukum DE JURE, Volume 17, Nomor 3, September 2017.

Soemantri, Sri, Prosedur dan Sistem Perubahan Konstitusi, Bandung: Alumni, 1987.

Yudi Latief, Negara Paripurna: Historisitas, Rasionalitas, dan Aktulitas Pancasila, Jakarta: Kompas Gramedia, 2001.

, Rancang Bangun GBHN, Kompas, Edisi 30 Agustus 2016. 
Undang-Undang Republik Indonesia Nomor 17 Tahun 2007 tentang Rencana Pembangunan Jangka Panjang Nasional Tahun 2005- 2025 (Lembaran Negara Republik Indonesia Tahun 2007 Nomor 33, Tambahan Lembaran Negara Republik Indonesia Nomor 4700).

Undang-Undang Nomor 12 Tahun 2011 Tentang Pembentukan Peraturan PerundangUndangan. (Lembaran Negara Republik Indonesia Tahun 2011 Nomor 82, Tambahan Lembaran Negara Republik Indonesia Nomor 5234).

Undang-Undang Nomor 23 Tahun 2014 tentang Pemerintahan Daerah (Lembaran Negara Republik Indonesia Tahun 2014 Nomor 244, Tambahan Lembaran Negara Republik Indonesia Nomor 5587).

\section{Risalah dan Internet:}

Sekretariat Negara, Himpunan Risalah Sidang-Sidang Badan Penyelidik Usaha Kemerdekaan Indonesia (BPUPKI) tanggal 29 Mei - 16 Juli 1945 dan Panitia Persiapan Kemerdekaan Indonesia (PPKI), tanggal 18-19 Agustus 1945 Yang Berhubungan Dengan Penyusunan Undang-Undang Dasar 1945.

https://www.gov.ie/en/publication/d5bd8c-constitution-of-ireland/, diunduh tanggal 22 November 2020, Pukul 15.15 WIB.

http://legislative.gov.in/constitution-of-india, diunduh tanggal 22 November 2020, Pukul 5.34 WIB.

https://www.constituteproject.org/constitution/Philippines_1987.pdf?lang=en, diunduh pada tanggal 22 November 2020, Pukul 12.51 WIB.

https://www.globalhealthrights.org/wp-content/uploads/2013/09/Brazil-constitutionEnglish.pdf, diunduh pada tanggal 22 November 2020, Pukul 15.19 WIB.

https://www.constituteproject.org/constitution/Republic_of_Korea_1987.pdf?lang=en, diunduh pada tanggal 22 November 2020, Pukul 13.58 WIB. 